\title{
DOEERR/75894-TT \\ The PEAK Experience in South Carolina
}
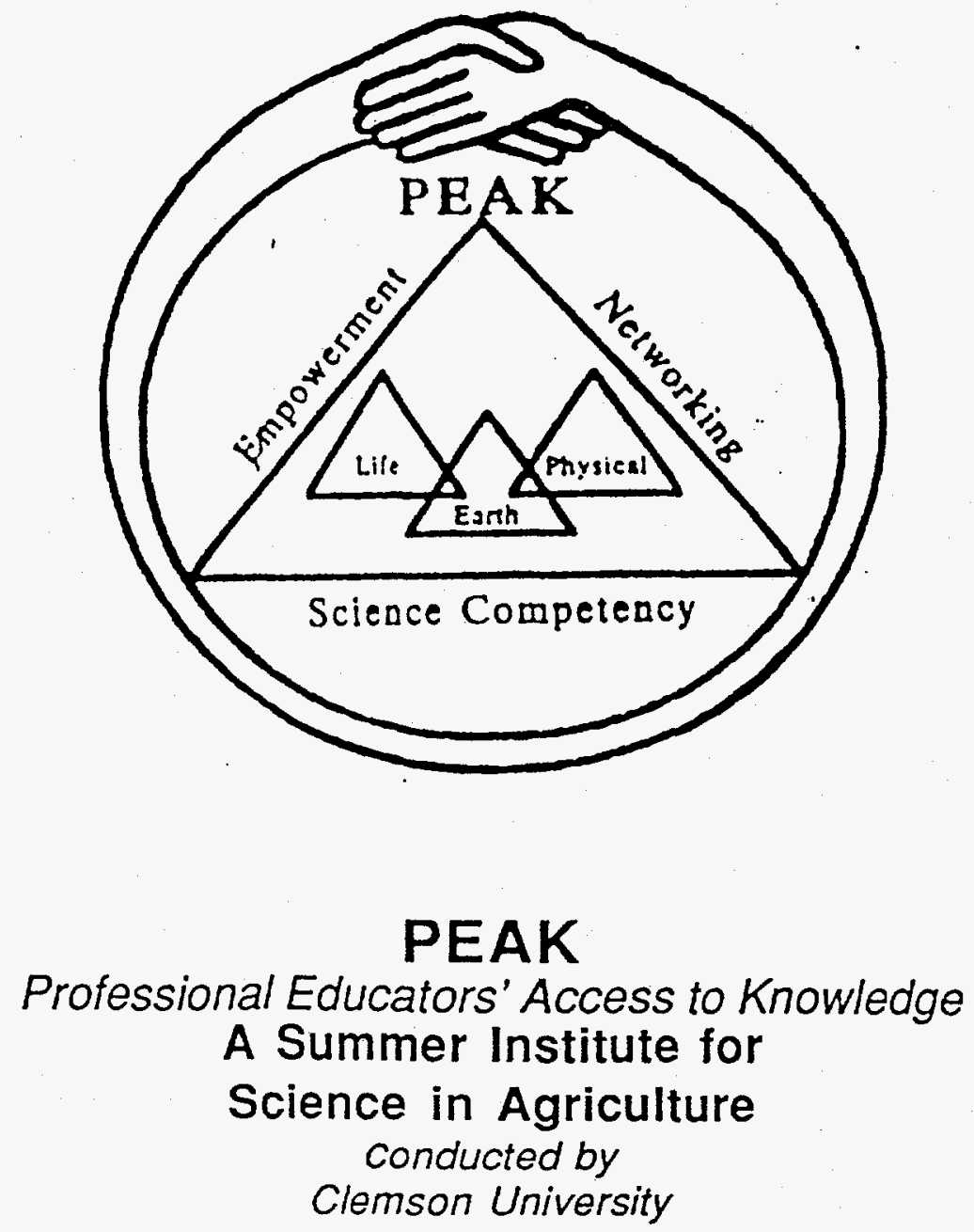

DISTRBBUTION OF THS DOCUNEMT IS UMLMTEO

Directors: Dr. Gloria McCutcheon

Pee Dee Research

\& Education Center
Dr. David Weatherford

Family and Youth Development

Department
APPROVED FOR RELEASE OR

PUBLICATION. INTEL. PROP. GP., OFC. OF CHIEF COUNSEL, DOE/ORO
MASTER 


\section{DISCLAIMER}

This report was prepared as an account of work sponsored by an agency of the United States Government. Neither the United States Government nor any agency thereof, nor any of their employees, makes any warranty, express or implied, or assumes any legal liability or responsibility for the accuracy, completeness, or usefulness of any information, apparatus, product, or process disclosed, or represents that its use would not infringe privately owned rights. Reference herein to any specific commercial product, process, or service by trade name, trademark, manufacturer, or otherwise does not necessarily constitute or imply its endorsement, recommendation, or favoring by the United States Government or any agency thereof. The views and opinions of authors expressed herein do not necessarily state or reflect those of the United States Government or any agency thereof. 


\section{DISCLAIMER}

Portions of this document may be illegible in electronic image products. Images are produced from the best available original document. 
This report serves as the final report for Grant \# 94-39236-0747 entitled " STEP Summer Teaching Institute". The PEAK Institute was developed to provide a linkage for formal (schoolteachers) and nonformal educators (extension agents) with agricultural scientists of Clemson University's South Carolina Agricultural Experiment Station System. The goal of the Institute was to enable teams of educators and researchers to develop and provide PEAK science and math learning experiences related to relevant agricultural and environmental issues of local communities for both classroom and 4-H Club experiences.

The Peak Institute was conducted through a twenty day residential Institute held in June for middle school and high school teachers who were teamed with an Extension agent from their community. These educators participated in" hands-on, minds-on" sessions conducted by agricultural researchers and Clemson University Cooperative Extension specialists. Participants were given the opportunity to see "frontier science" being conducted by scientists from a variety of agricultural laboratories.

Scientists, earlier in the year had received training to become more sensitive to the needs of the teachers and youth so that more meaningful learning experiences might be developed. Scientists also provided a yearlong mentoring relationship with the teachers to help the teachers more fully appreciate the work of an agricultural scientist and help provide more relevant experiences for the young people. Teams of educators received incentive grants to develop "PEAK Experience Projects" with their students centered on a local agricultural or environmental issue while supporting existing math and science curricula. . A Program Development Template proposed by the funding source was adapted by the PEAK Project and entitled "PEAK Experience Program Development Template" and partially tested in the last year of the funding.

During its funding history the PEAK Institute reached into fifteen of the forty-six counties of South Carolina with seventy-four educators participating. Conservatively 
estimating, twenty thousand youth were impacted in some way by PEAK programs through the resultant classroom and 4-H club programs. Examples of PEAK Projects that were conducted included Heritage River Sweep, "CORE: Conservation Of Resources and the Environment", and "Learningscapes: Natural School Learning Areas ", "Project Vegetable Soup", "Plant Growth and Development in a Greenhouse", "Science and Food Production" and "Cotton: From the Seed to the Consumer". Another major project entitled SEEKERS and funded by National Science Foundation was a direct offshoot of one of the initial PEAK projects

Based on the two years of information which were based on reports of the participating teachers and agents the following conclusions were drawn.

1) The utilization of agricultural issues and concepts served as a useful vehicle by teachers at the middle school level for teaching science and mathematical curriculum.

2) Teachers were unaware of the wealth of resources available to them from the land grant universities through their local Extension Service offices and their regional Research and Education centers.

3) Extension agents and researchers of the land grant system were unaware of the needs of the local school systems and the potential assistance that could be provided to the respective teachers.

4) The Summer Institute impacted most of the participating teachers dramatically in many positive ways; however, these impacts were not always translated into classroom improvements.

5) Factors which affected classroom improvement included:

a) degree of independence allowed teacher upon return to classroom by school administration, 
b) jealousy expressed by other teachers at PEAK teacher's school for PEAK teacher's new resources,

c) nearness of school to regional Research and Education centers,

d) tenure of teacher,

e) personal energy level and ambitiousness of teacher,

f) type and degree of response of agent in working with teachers,

g) using a team approach at the Institute with teachers from several schools within a county school system proved to be unworkable upon return home, and

h) using a team approach within a school allowed more positive interactions and successful programming efforts.

6) Specific impacts on individual teachers included decisions to work on advanced degrees, more creative classrooms, expanded understandings of how to provide relevancy to their classroom programs, increased abilities to obtain resources for the classroom (financial, physical, and people), and utilization of support networks with other teachers across the state. Unexpected impacts included retirements and greater frustrations with inability to do what they really wanted to do in the classroom.

7) The intended continued format of the Institute based on PEAK Teachers with alumni teachers selected to assume Institute leadership had begun to be initiated with good success.

8) Early termination of the program resulted in loss of continuity, network, support and later opportunities for success. This situation eliminated most of the reinforcing mechanisms which would have allowed encouragement and continued support of individual teachers as they tried to implement the PEAK concept in their respective schools. 
9) Positive support was received from University administration, school administrators and business partners for the basic concept the PEAK program advocated.

10) Many teachers and school systems, as well as Extension staff were anxiously awaiting their turn to become part of the PEAK Program before the program was prematurely ended.

11) Regional Science and Math Hubs were aware of the success of the PEAK Program and one HUB provided financial support to allow an abbreviated version of PEAK to be offered locally.

12) Science and Math Hubs across the state have since developed a teacher leadership program which in many ways parallels the empowerment efforts of the PEAK Institute but without its attention to agricultural issues or the resources available from the Research and Education Centers.

13) Pilot counties were located mostly in the Pee Dee section of the state. Plans were made to develop additional Institutes in other parts of the state to encourage more teacher participation from those parts of the state.

14) A healthy dialogue developed between Cooperative Extension specialists and other University researchers and administrators on the needs of education and solutions to those needs that could be provided by the University.

15) Recognition by the traditional state school system and science and math education specialists with the potential resources and abilities of the agricultural research and Extension systems. 


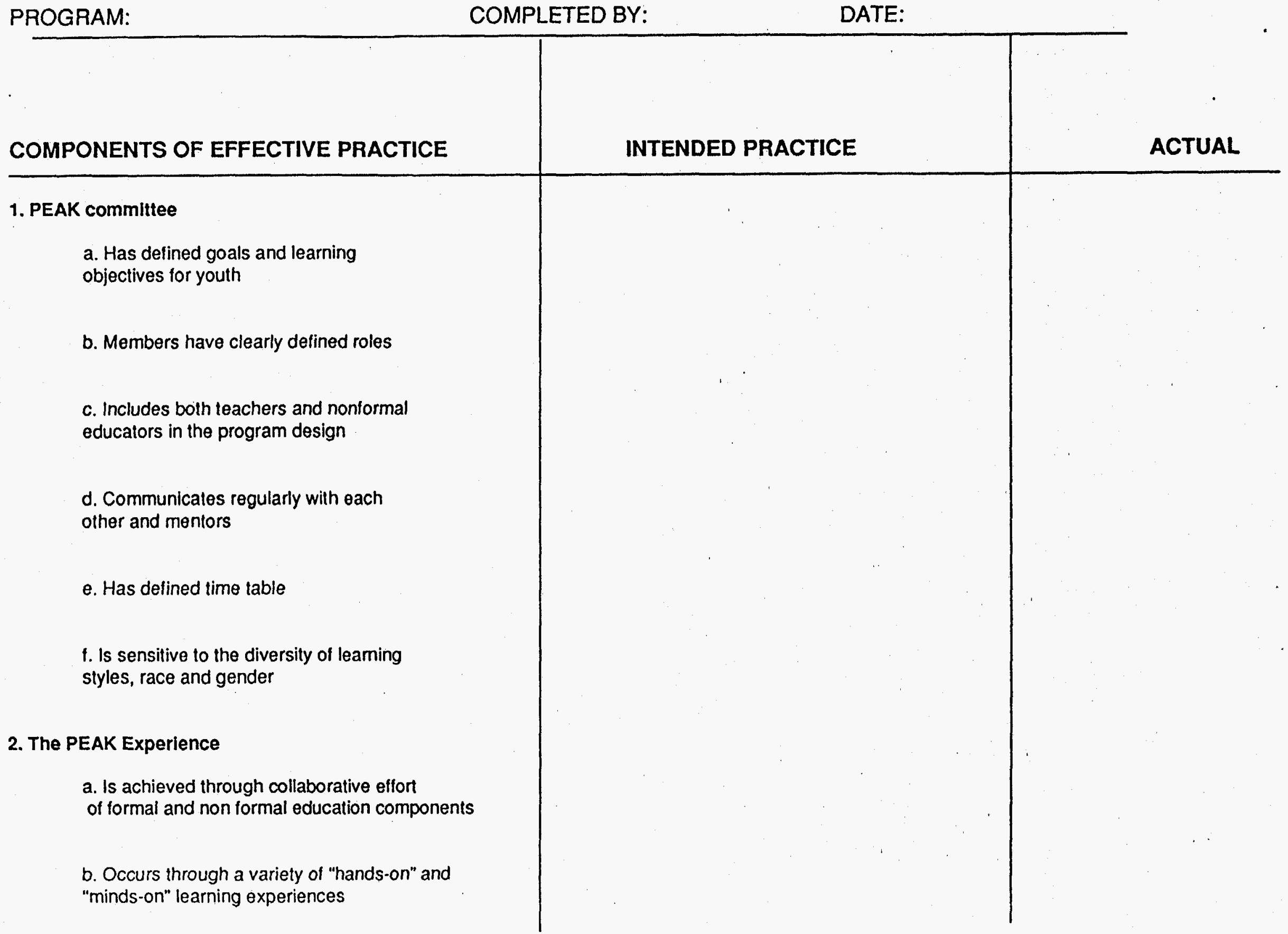


c. Allows learner to apply basic science skills on

relevant issues

d. Utilizes up-to-date resources from a variety

of educational, industrial or other agencies

e. Allows group work and opportunities for team development

f. Encourages creativity

\section{Contribution to formal education and} nonformal education missions

a. Some experiences support and reinforce the objectives set forth by standardized goals established as criteria for the school system

b. Some experiences support the initiatives and directives of the plans of work or mission objectives for nonformal agencies

c. Experiences mutually reinforce each other over time 
4. Involvement of agricultural laboratory resources

a. Mentors are a relied upon source of support for educators

b. Lab resources are utilized in leaming experiences

c. Scientists are invited to be a part of the planning process as well as provider of experiences

\section{PEAK Experience Evaluation}

a. Monitoring of youth progress during school year as related to PEAK experience

b. Complete update reports to directors before January and April

c. Prepare final report for April summation conference 
6. Youth Leadership

a. Youth should be involved in planning and implementation of some Peak experiences

b. Cross age teaching or youth mentoring is a part of some experiences

c. End of project review by a youth panel 